\title{
Radiocarbon
}

1970

\section{ANU RADIOCARBON DATE LIST IV}

\section{H. A. POLACH, ${ }^{*}$ J. F. LOVERING, ${ }^{*} *$ and J. M. BOWLER $\dagger$}

Australian National University, Canberra, Australia

The present date list describes the first stage of a co-operative study on the validity of dating secondary soil carbonates in arid and semi-arid environments of Australia. Because of the complex nature of the physical and chemical variables in a soil environment, many additional samples are being dated from stratigraphically controlled sites before final evaluation of carbonate reliability is possible.

All measurements were performed on a Beckman LS-200 liquid scintillation spectrometer following automatic cycling procedures described previously (Radiocarbon, 1969, v. 11, p. 245; Polach, 1969). In a recent paper (Geyh, 1969), auto-production of acetylene due to carbon impurities of commercial lithium metal, is reported. For our acetylene synthesis described by Polach and Stipp (1967) we use: dry pack, low-sodium-grade lithium metal shot, produced by Lithium Corp. of America, Inc., New York. It is free of traces of carbon and is directly suitable for $\mathrm{C}_{2} \mathrm{H}_{2}$ production if kept in an inert atmosphere. All ages are reported relative to A.D. 1950 on the basis of Libby half-life $(5570 \pm 30)$. B.C. and A.D. ages have not been calculated, for this geologic series, but $\delta \mathrm{C}^{13}, \delta \mathrm{C}^{14}$, and $\Delta$ terms in parts per $(\% \circ)$ are reported as in our previous date list (cf. Radiocarbon, 1969, v. 11, p. 245-262).

\section{ACKNOWLEDGMENTS}

We wish to acknowledge assistance of J. Golson, Dept. of Prehistory, A.N.U. We also thank T. A. Rafter, Dir., Inst. Nuclear Sciences, New Zealand, for allowing one of us (H.A.P.) to determine $\mathrm{C}^{13} / \mathrm{C}^{12}$ ratios within the mass spectrometry section of the Institute, and G. E. Williams, Dept. of Geology, University of Adelaide, for critical reading of manuscript. J. M. B. wishes to thank J. Head, Technical Officer, Radiocarbon Lab., for tuition and supervision whilst dating his own samples.

\section{SAMPLE DESCRIPTIONS}

I. GEOLOGIC SAMPLES

\section{Australia}

\section{A. Validity of carbonate nodule dating}

Field study undertaken by J. M. Bowler. Porous, nodular, or fineearth carbonates were selected from red calcareous and red-brown earth

* Dept. of Geophysics and Geochemistry and Dept. of Prehistory

** Dept. of Geophysics and Geochemistry. Present address: Dept. of Geology, University of Melbourne, Melbourne, Victoria

+ Dept. of Biogeography and Geomorphology 
soils (Stace et al., 1968) in the low-rainfall Mallee and Riverine Plain of $\mathrm{N}$ Victoria and from a chernozemic soil on the Keilor terrace near Melbourne (Bowler, 1969a).

Sites were selected along a transect, across Victoria, with a steep temperature and precipitation gradient. Mean annual pan evaporation ranges from ca. $150 \mathrm{~cm}$ near Nyah West in semi-arid Mallee to $100 \mathrm{~cm}$ at Melbourne whereas precipitation varies from $30 \mathrm{~cm}$ to $70 \mathrm{~cm}$. Samples were only obtained where stratigraphic control was already available, permitting independent estimates of soil age. Samples coll. by Bowler and Polach in 1967, and recoll. by Bowler in 1968. Subm. by Dept. of Biogeography and Geomorphology.

\section{Nyah West series}

Samples obtained near Nyah West Railway Sta. $\left(35^{\circ} 20^{\prime}\right.$ S Lat, $143^{\circ}$ $23^{\prime}$ E Long) in cut through EW longitudinal dune. Dunes now are fixed by vegetation, but are continuous with extensive inland dune system of central Australia. Sequence of buried calcareous soils (Hills, 1939) reflects Quaternary paleoenvironments in which landscape instability and dune building alternated with stability and soil formation (Churchward, 1961). Surface of cut, weathering for ca. $50 \mathrm{yr}$, cleaned back 5 to $10 \mathrm{~cm}$ to permit sampling of carbonate horizons $15 \mathrm{~cm}$ thick.

ANU-183.

$$
\begin{array}{rlr}
\delta C^{14} & =-849.4 \pm 4.3 & \mathbf{1 5 , 5 5 0} \pm \mathbf{2 3 0} \\
\Delta & =-855.7 \pm 4.1 & \delta C^{13}=-4.9 \pm 0.2 \%
\end{array}
$$

Fine earth carbonate in $B$ horizon, $65 \mathrm{~cm}$ deep in hight (Kyalite) (Churchward, 1961). Benzene, 1380 min. count.

ANU-184.

$$
\begin{array}{rlr}
\delta C^{14} & =-947.6 \pm 5.9 & \mathbf{2 4 , 0 0 0} \pm \mathbf{9 0 0} \\
\Delta & =-949.7 \pm 5.6 & \delta C^{1.3}=-5.1 \pm 0.2 \%
\end{array}
$$

Porous nodular carbonate from 2nd soil unit (Speewa) (Churchward, 1961), $235 \mathrm{~cm}$ deep. Benzene, $1440 \mathrm{~min}$. count.

ANU-185.

$$
\begin{aligned}
& \delta C^{14}=-974.2 \pm 4.2 \\
& +\mathbf{1 4 5 0} \\
& \mathbf{2 9 , 7 5 0} \\
& \Delta=-975.3 \pm 4.1 \quad \delta C^{13}=-4.7 \pm 0.2 \%
\end{aligned}
$$

Porous nodular carbonate from lowest soil unit (Bymue) (Churchward, 1961), $385 \mathrm{~cm}$ deep. Benzene, $1560 \mathrm{~min}$. count.

General Comment (J.M.B.): results are consistent with sequence of soil formation. Independent estimates of age of last period of instalibity were between 16,000 and 20,000 B.P. Soil carbonate is younger than deposit in which it formed but time relationship between deposition and pedogenesis is not clear. All 3 ages are minimum for assoc. sedimentary units. Carbonate for youngest Kyalite unit was provided by erosion of older exposed pedologic carbonates (Churchward, 1961). During translocation through profile, carbonate acquired sufficient younger atmospheric $\mathrm{C}^{14}$ considerably to reduce contamination by older carbon. Further 
$\mathrm{C}^{14}$ uptake of Speewa was effectively prevented by deposition of the younger Kyalite layer (ANU-183), probably since 24,000 в.P. Low levels of $\mathrm{C}^{14}$ activity in all samples indicate that little atmospheric or soil $\mathrm{CO}_{2}$ has been taken up by carbonate due to exposure to direct weathering since cut was made.

\section{Kerang series}

Samples from soil profile in quarry $\mathrm{S}$ of Quambatook $5 \mathrm{mi} \mathrm{W}$ of Kerang ( $35^{\circ} 46^{\prime} \mathrm{S}$ Lat, $143^{\circ} 47^{\prime} \mathrm{E}$ Long); $2 \mathrm{~m}$ calcareous red sandy clay overlie lateritized and silicified sandstone of probably Upper Tertiary age. Soil mantle being developed on materials of eolian origin of late Quaternary age.

$$
\text { ANU-181. } \begin{aligned}
\delta C^{14} & =-492.3 \pm 5.8 \\
\Delta & =-513.6 \pm 5.6
\end{aligned} \quad \delta C^{13}=-4.8 \pm 0.2 \%
$$

Fine-earth carbonate, $10 \mathrm{~cm}$ deep. Benzene, $1260 \mathrm{~min}$. count.

$$
\text { ANU-182. } \quad \begin{array}{rlr}
\delta C^{14} & =-701.6 \pm 5.1 & \mathbf{1 0 , 0 6 0} \pm \mathbf{1 4 0} \\
\Delta & =-714.2 \pm 4.9 & \delta C^{13}=-4.7 \pm 0.2 \% 0
\end{array}
$$

Porous carbonate concretions, $60 \mathrm{~cm}$ deep. Benzene, $1380 \mathrm{~min}$. count. General Comment (J.M.B.): both dates are believed to be much younger than true age of carbonate organization. At this site, higher rainfall and shallow burial resulted in more rapid uptake of atmospheric carbon, as compared with dune environment to $\mathrm{W}$, where horizons dated (ANU183) are believed ca. of same age.

\section{Echuca series}

ANU-90.

$$
\begin{aligned}
& \delta C^{14}=-572.8 \pm 5.0 \quad \mathbf{7 1 1 0} \pm \mathbf{9 5} \\
& \Delta=-587.3 \pm 4.9 \quad \delta C^{13}=-8.9 \pm 0.2 \%
\end{aligned}
$$

Carbonate concretion, $30 \mathrm{~cm}$ deep in levee of Kanyapella prior stream (36 $06^{\circ} \mathrm{S}$ Lat, $144^{\circ} 53^{\prime} \mathrm{E}$ Long) (Bowler and Harford, 1966) 8.5 $\mathrm{mi} \mathrm{E}$ of Echuca. Levee truncated by lake and lunette and antedates Ancestral River II phase for which an age ca. 16,000 в.P. (Bowler, 1967) is available for comparison, Benzene, 1400 min. count. Comment (J.M.B.): high uptake of atmospheric $\mathrm{C}^{14}$ as indicated during and since carbonate segregation.

ANU-135.

$$
\begin{aligned}
\delta C^{14} & =-547.1 \pm 4.8 \\
\Delta & =-565.3 \pm 4.6 \quad \delta C^{13}=-6.0 \pm 0.2 \%
\end{aligned}
$$

Carbonate concretion from gravel pit in bed of prior stream of Campaspe system (Bowler and Harford, 1966) $5.5 \mathrm{mi} \mathrm{NE}$ of Rochester $\left(36^{\circ} 20^{\prime}\right.$ S Lat, $144^{\circ} 46^{\prime} \mathrm{E}$ Long) coll. from $\mathrm{B}_{\mathrm{ca}}$ horizon, $110 \mathrm{~cm}$ deep in red-brown earth soils typical of those developed over large region of Riverine Plain. Similar sediments and soils dated on Goulburn R. $10 \mathrm{mi}$ E, indicate that these soils are older than 15,000 B.P. Coll. 1967. Benzene, 1520 min. count. 
ANU-291.

$$
\begin{aligned}
\delta C^{14} & =-521.9 \pm 5.7 \\
\Delta & =-541.0 \pm 5.8
\end{aligned}
$$

$6260 \pm 100$

Est. $\delta C^{13}=-5.0 \pm 2.0 \%$.

1968 recollection of ANU-135. Benzene, 980 min. count. Comment (J.M.B.): high levels of $\mathrm{C}^{14}$ activity again indicate high percentage of soil and atmospheric $\mathrm{C}^{14}$ incorporated into crystal lattice after initial carbonate nodule formation. The close correspondence of ANU-135 and 291 collected in different years, in different parts of soil pit, but within same horizon indicates good consistency and reproducibility of results within site.

\section{Shepparton series}

ANU-134.

$$
\begin{aligned}
\delta C^{14} & =-254.0 \pm 6.3 \\
\Delta & =-282.4 \pm 6.1 \quad \delta C^{13}=-7.0 \pm 0.2 \%
\end{aligned}
$$

Massive-carbonate concretion, $180 \mathrm{~cm}$ deep in profile of red-brown earth developed on prior stream sediments exposed in right bank of Goulburn R. 3 mi S of Shepparton ( $36^{\circ} 25^{\prime} \mathrm{S}$ Lat, $145^{\circ} 21^{\prime} \mathrm{E}$ Long). Sediments on which these soils formed have been dated at ca. 25,000 and 30,000 B.P. (Bowler, 1967). Since red-brown earth soils are not found on younger alluvium dated at ca. 5000 B.P., 8000 B.P., and 16,000 B.P., we infer age of soil formation of Shepparton series to be ca. 15,000 B.P. Coll. 1967. Benzene, 1400 min. count.

ANU-290.

$$
\begin{array}{rlr}
\delta C^{14} & =-239.7 \pm 6.8 & \mathbf{2 5 3 0} \pm \mathbf{8 0} \\
\Delta & =-270.1 \pm 7.2 & \text { Est. } \delta C^{13}=-5.0 \pm 2.0
\end{array}
$$

1968 recollection of ANU-134. Benzene, 1100 min. count. Comment (J.M.B.): very high levels of $\mathrm{C}^{14}$ activity again reflect continuation of incorporation of atmospheric- and soil $\mathrm{CO}_{2}$ after initial carbonate-nodule formation due to subsequent mobilization within profile, here attributed to higher rainfall. Comment (H.A.P.) we note that 1968 recollection of ANU-135 within Echuca series, and of ANU-134 within Shepparton series, are younger than their equivalent 1967 collections but no conclusions can be drawn from 2 determinations alone.

\section{Keilor series}

$$
\text { ANU-126. } \quad \begin{aligned}
\delta C^{14} & =-184.5 \pm 6.5 \\
\Delta & =-222.0 \pm 6.2 \quad \delta C^{13}=-2.3 \pm 0.2 \%
\end{aligned}
$$

Carbonate nodules 8 to $10 \mathrm{~cm}$ diam., from Keilor terrace near Green Gully, $1 \mathrm{mi} \mathrm{S}$ of Keilor, (37 $45^{\prime} \mathrm{S}$ Lat, $144^{\circ} 50^{\prime} \mathrm{E}$ Long) in site previously subjected to intensive stratigraphic study in connection with Late Quaternary occupation and human remains (Bowler et al. 1967; Bowler, 1969). Limiting ages of carbonate segregation have been reliably placed here between 6000 and 11,000 B.P. Moreover, human remains buried in $\mathrm{B}_{\mathrm{ca}}$ horizon of chernozemic soil and bearing a thin encrustation of carbonate have been dated as follows: bone collagen, $6460 \pm 190$ в.P. (NZ-676) bone carbonate, $1781 \pm 115$ B.P. (NZ-675, Rafter, pers. commun.). Comment (H.A.P.): results from both bone and soil carbonate are in close agree- 
ment and demonstrate that here bone carbonate directly reflects carbonate environment of soil in which it is found (cf. Haynes, 1968).

General Comments (J.M.B. and H.A.P.): all samples from higher rainfall areas show high levels of $\mathrm{C}^{14}$ activity due to exchange between atmospheric and soil $\mathrm{CO}_{2}$. In drier semi-arid environment, infrequent wetting has resulted in ages which are regarded as consistent with independent stratigraphic evidence and close to the actual age of carbonate organization. Circumstances necessary for segregation and migration of carbonate to form nodules or crusts, are those most suited to uptake of modern soil- and-atmosphere derived $\mathrm{C}^{14}$. Where nodular carbonate has been dated in this series, ages obtained are considerably younger than independent estimates. The buried soil nodular carbonates at Kerang (ANU-182) and Nyah West (ANU-184 and 185) give minimum ages for deposition of sediment and subsequent soil formation. Age of continental dune system therefore extends beyond 30,000 B.P., an estimate consistent with independent stratigraphic evidence (Bowler, 1969). In region studied, all dates obtained from soil carbonates are younger than ages of sediment on which they were formed, demonstrating apparent independence of $\mathrm{C}^{14}$ levels of source carbon. This relationship can be applied to carbonate samples when more reliable dating materials are not available. While demonstrating some difficulties of carbonate dates from subhumid regions, results point to greater reliability of such materials in semiarid and arid regions.

B. Extension of carbonate nodule dating project to

Quaternary geochronology of Lake Torrens area, South Australia

\section{Lake Torrens series}

Field study in Lake Torrens region of South Australia (mean annual precipitation $<25 \mathrm{~cm}$ ), by G. E. Williams, Dept. of Geol., Univ. of Adelaide. Charcoal from parent sedimentary formations has furnished an absolute chronology to which dates for authigenic soil carbonate can be related. Samples will be checked for $\mathrm{C}^{13} / \mathrm{C}^{12}$ ratios by Geochron Lab., Inc., U.S.A.; in the meantime value, $\delta \mathrm{C}^{13}=-5.0 \pm 2 \%$, as derived from study by Bowler was applied. Samples coll. 1967 and 1968 by G. E. Williams; subm. by Dept. of Geophysics.

ANU-213.

$$
\begin{array}{r}
\Delta=-303.9 \pm 16.8 \\
\text { Est. } \delta C^{13}=-24.0 \pm 2.0 \%
\end{array}
$$

Charcoal fragments from gravelly alluvium, near "apex" of large fan, Wilkatana Sta. ( $32^{\circ} 07^{\prime} \mathrm{S}$ Lat, $137^{\circ} 57^{\prime} \mathrm{E}$ Long) $30 \mathrm{mi} \mathrm{N}$ of Pt. Augusta, S.A. Benzene dilution, 1000 min. count. Comment (G.E.W.): Some doubt as to origin of charcoal; age is minimum for terrace.

ANU-214.

$$
\Delta=-472.0 \pm 6.2
$$

$$
\text { Est. } \delta C^{1 s}=-24.0 \pm 2.0 \%
$$

Charcoal fragments from gravelly alluvium near apex of Depot Creek Fan (32 $13^{\prime} \mathrm{S}$ Lat, $137^{\circ} 55^{\prime} \mathrm{E}$ Long) $25 \mathrm{mi} \mathrm{N}$ of Pt. Augusta. 
Benzene, 1000 min. count. Comment (G.E.W.): date more reliable than ANU-213, indicating that large segment of fan was aggraded during mid-Holocene.

ANU-215.

$$
\begin{array}{rr}
\Delta=-199.7 \pm 40.0 & \mathbf{1 7 9 0} \pm \mathbf{4 0 0} \\
\text { Est. } \delta C^{13}=-24.0 \pm 2.0 \% 0
\end{array}
$$

Charcoal fragments from Wilkatana Fan, youngest terrace. Benzene, 1020 min. count.

$$
\begin{array}{rr}
\Delta=-347.6 \pm 6.5 & \mathbf{3 4 3 0} \pm \mathbf{8 0} \\
\text { Est. } \delta C^{13}=-24.0 \pm 2.0 \% 0
\end{array}
$$

Charcoal from terrace, central area of Wilkatana Fan. Benzene, 1220 min. count.

$$
\begin{array}{rr}
\text { ANU.217. } \quad \Delta=-208.4 \pm 8.2 & \mathbf{1 8 8 0} \pm \mathbf{8 5} \\
\text { Est. } \delta C^{13}=-24.0 \pm 2.0 \%
\end{array}
$$

Charcoal fragments from Depot Creek Fan, youngest terrace. Benzene, 860 min. count.

$$
\begin{array}{rr}
\Delta=-526.4 \pm 6.1 & \mathbf{6 0 0 0} \pm \mathbf{1 0 0} \\
\text { Est. } \delta C^{13}=-24.0 \pm 2.0 \%
\end{array}
$$

Charcoal fragments from terrace at base of Depot Creek Fan, which correlates with ANU-214, mid-Holocene fan segment and with alluvium locally flooring interdune corridors further $\mathrm{N}$ at Motpena Sta. (ANU-265). Benzene, 860 min. count. Comment (G.E.W.): fine earth carbonate from same formation and immediately above ANU-219 yields $6450 \pm 90$ B.P., ANU-224.

ANU.220.

$$
\Delta=-163.4 \pm 8.3
$$

$1430 \pm 80$

Est. $\delta C^{13}=-24.0 \pm 2.0 \%$

Charcoal fragments from sand ridge area at base of Depot Creek Fan. Benzene, 860 min. count.

$$
\begin{array}{rr}
\Delta=-153.4 \pm 8.1 & \mathbf{1 3 4 0} \pm \mathbf{8 0} \\
\text { Est. } \delta C^{13}=-24.0 \pm 2.0 \% \circ
\end{array}
$$

Charcoal fragments, ca. $60 \mathrm{~cm}$ deep, from fan emerging from Chambers Gorge, NE Flinders Ranges ( $30^{\circ} 58^{\prime} \mathrm{S}$ Lat, $139^{\circ} 17^{\prime}$ E Long). Benzene, 1020 min. count.

ANU-222.

$$
\begin{aligned}
& \Delta=-789.1 \pm 4.4 \\
& 12,500 \pm 170 \\
& \text { Est. } \delta C^{13}=-24.0 \pm 2.0 \%
\end{aligned}
$$

Charcoal fragments, $1.4 \mathrm{~m}$ below ANU-221, from base of clayey, silty sand, underlain by gravel. Benzene, $1000 \mathrm{~min}$. count.

ANU-223.

$$
\begin{aligned}
\delta C^{14} & =-612.7 \pm 5.1 \\
\Delta & =-628.2 \pm 5.1
\end{aligned}
$$
Wilkatana Fan. Benzene, 1020 min. count. Comment (G.E.W.): date for youngest calcareous soil on Lake Torrens plain. Soil correlates with that dated by ANU-224. 
ANU-224.

$$
\delta C^{14}=-533.6 \pm 4.7
$$

$6450 \pm 90$

$\Delta=-552.2 \pm 4.9$

Est. $\delta C^{13}=-5.0 \pm 2.0 \%$

Fine earth carbonate from same area at base of Depot Creek Fan as ANU-223. Benzene, $1660 \mathrm{~min}$. count. Comment (G.E.W.): compares and correlates with parent charcoal, ANU-219.

ANU-225. $\quad \delta C^{14}=-956.9 \pm 3.5$

$25,600 \pm 680$

$$
\Delta=-958.6 \pm 3.4 \quad \text { Est. } \delta C^{13}=-5.0 \pm 2.0 \%
$$

Alluvial clay containing nodules and patches of authigenic carbonate, near apex of Wilkatana Fan. Small pebbles of limestone and dolomite within same alluvium, late Pleistocene fan and valley fill, on Lake Torrens Plain. Other carbonates dating same horizon are ANU-226, 227, 264, 282 and probably also ANU-127. Benzene, 1020 min. count.

ANU-226.

$$
\begin{aligned}
\delta C^{14} & =-979.0 \pm 2.7 \\
\Delta & =-979.8 \pm 2.6
\end{aligned}
$$

$31,360 \pm 1000$

Est. $\delta C^{13}=-5.0 \pm 2.0 \%$ o

Pebbly mudstone, containing numerous nodules of authigenic $\mathrm{CaCO}_{3}$. Small pebbles of limestone occur in the alluvium, taken from apex of Depot Creek Fan. See ANU-225 for other related samples. Benzene, 1960 min. count. Comment (G.E.W.): anomalously great age attributed to inclusion of detrital fragments of ancient limestone, distinguishable in thin section.

ANU-227.

$$
\begin{aligned}
\delta C^{14} & =-934.6 \pm 3.6 \\
\Delta & =-937.2 \pm 3.5
\end{aligned}
$$

Est. $\delta C^{13}=-5.0 \pm 2.0 \%$

Pebbly mudstone, containing large nodules of authigenic $\mathrm{CaCO}_{3}$, base of Depot Creek Fan. Small pebbles of limestone and dolomite occur in sediment. Benzene, $1000 \mathrm{~min}$. count.

$$
\text { ANU-228. } \quad \begin{array}{rlr}
\delta C^{14} & =-944.0 \pm 3.8 \\
\Delta & =-946.3 \pm 3.7 & \text { Est. } \delta C^{13}=-5.0 \pm 2.0 \%
\end{array}
$$

Fault gouge cemented by $\mathrm{CaCO}_{3}$, fault cutting Pleistocene sediments at apex of Wilkatana Fan ca. $3 \mathrm{~m}$ above bed of modern wash. Date correlates with ANU-225. Benzene, $860 \mathrm{~min}$. count.

$$
\begin{aligned}
& \text { ANU-263A. } \\
& \Delta=-236.3 \pm 10.1 \\
& 2160 \pm 110 \\
& \text { Est. } \delta C^{13}=-24.0 \pm 2.0 \%
\end{aligned}
$$

Fragments of carbonized wood from base of vertical bank on $\mathrm{N}$ side of Hookina Creek ( $31^{\circ} 44^{\prime} \mathrm{S}$ Lat, $138^{\circ} 14^{\prime} \mathrm{E}$ Long) next to HawkerCotabena Rd. Benzene, 860 min. count. Comment (G.E.W.): dates youngest terrace along Hookina Creek and correlates with ANU-215 and 217 further $S$.

$$
\text { ANU-264. } \quad \begin{array}{rlr}
\delta C^{14} & =-939.6 \pm 3.6 & \mathbf{2 2 , 9 0 0} \pm \mathbf{5 0 0} \\
\Delta & =-942.0 \pm 3.5 & \text { Est. } \delta C^{13}=-5.0 \pm 2.0 \%
\end{array}
$$

Red clayey silt and fine sand cemented with $\mathrm{CaCO}_{3}$ and gypsum with possibly limestone pebbles in alluvium. Interdune corridor in sandridge country $\mathrm{W}$ of Parachilna (31 $11^{\prime} \mathrm{S}$ Lat, $138^{\circ} 15^{\prime} \mathrm{E}$ Long), dating basement soil in "Motpena" australite-strewn field. 
ANU.265.

$$
\Delta=-524.2 \pm 5.9
$$

$6000 \pm 100$

Est. $\delta C^{1 s}=-24.0 \pm 2.0 \%$ o

Charcoal grains within fine sand flooring interdune corridor in sandridge country W of Parachilna. Correlates with ANU-214 and 219. Should date youngest australite-bearing formation in "Motpena" strewn field. Benzene, 1000 min. count.
ANU-280.
$\delta C^{14}=-860.1 \pm 4.4$
$\Delta=-865.7 \pm 4.2$
$16,130 \pm 250$
Est. $\delta C^{13}=-5.0 \pm 2.0 \%$

Carbonate cylindroids from calcareous soil within sand ridge area near Nacoona $\left(32^{\circ} 15^{\prime} \mathrm{S}\right.$ Lat, $137^{\circ} 50^{\prime} \mathrm{E}$ Long) ca. $20 \mathrm{mi} \mathrm{N}$ of Pt. Augusta. Benzene, 820 min. count. Comment (G.E.W.): soil developed within sand dunes regarded as second youngest soil on the Lake Torrens Plain. Dated elsewhere on the plain by ANU-281 and probably also ANU-100 and 132 , mean value ca. 14,000 в.P.
ANU-281. $\delta C^{14}=-767.1 \pm 4.5 \quad \mathbf{1 2 , 0 5 0} \pm \mathbf{1 6 0}$
$\Delta=-776.4 \pm 4.4 \quad$ Est. $\delta C^{13}=-5.0 \pm 2.0 \%$

Carbonate cylindroids and nodules from exposed surface of old dune sands, Motpena Sta. ( $31^{\circ} 12^{\prime} \mathrm{S}$ Lat, $138^{\circ} 16^{\prime} \mathrm{E}$ Long) correlates with ANU-280. Benzene, $980 \mathrm{~min}$. count.

$$
\text { ANU-282. } \quad \begin{aligned}
\delta C^{14} & =-493.8 \pm 5.8 \\
\Delta & =-514.1 \pm 5.9 \quad \text { Est. } \delta C^{13}=-5.0 \pm 2.0 \%
\end{aligned}
$$

Carbonate nodules from calcareous soil, 10 to $30 \mathrm{~cm}$ beneath interdune corridor, Motpena Sta. For other related dates, see ANU-225. Heavy rains cause torrential runoff over area where sample was coll. Benzene, 1000 min. count. Comment (H.A.P.): anomalously young age reflects atmospheric- $\mathrm{C}^{14}$ uptake of carbonates upon wetting.

ANU-283. $\delta C^{14}=-496.6 \pm 5.8 \quad \mathbf{5 8 4 0} \pm \mathbf{1 0 0}$

$$
\Delta=-516.8 \pm 5.9 \quad \text { Est. } \delta C^{13}=-5.0 \pm 2.0 \%
$$

Tubules of dense $\mathrm{CaCO}_{3}$, near base of terrace on N bank of Hookina Creek, where ANU-263A was coll. High water table, with sample site subject to periodic flooding. Tubules replace plant remains. Benzene, 1000 min. count.

ANU-302.

$$
\begin{aligned}
\delta C^{14} & =-797.0 \pm 4.2 \\
\Delta & =-805.1 \pm 4.1
\end{aligned}
$$

Carbonate nodules, from gleyed alluvium within vertical bank of Hookina Creek above present flood plain. Interpreted as "ground water calcrete" deposited during earlier phase of high water table. Benzene, 1100 min. count. Comment (H.A.P.): ANU-300, charcoal not yet dated; will provide control age for parent alluvium.

General Comment (G.E.W.): 3 calcareous paleosols of late Quaternary age are developed on Lake Torrens piedmont plain, South Australia. Mean radiocarbon ages for paleosols are in correct order at ca. 7200 B.P., 14,000 B.P., and 21,400 B.P. One sample from the oldest soil, ANU- 
$226,31,360 \pm 1000$ B.P., is anomalously old due to incorporation of dead limestone, whereas recrystallized authigenic carbonate from same paleosol, but in subchannel area subject to periodic flooding, yielded anomalously young age, ANU-282, $5800 \pm 100$ B.P. All other dates fall within acceptable range.

\section{Dating infall of australites (tektites)}

Study undertaken by J. F. Lovering, and B. Mason, Smithsonian Inst., Washington, D.C., and supplemented by stratigraphic evidence provided by G. E. Williams on occurrence and age of fall of australites. At time of fieldwork, these "ages" were reported. 1) K/Ar dating at 700,000 B.P. (Zähringer, 1963); similar K/Ar ages for tektites from Indonesia, Thailand, Indochina, and Philippines are also indicated. McDougall and Lovering (1969) provided further $\mathrm{K} / \mathrm{Ar}$ data, evaluated at $860,000 \mathrm{yr}$ for australites, 2) fission-track dating from 30,000 to 800,000 B.P. was interpreted as consistent with $\mathrm{K} / \mathrm{Ar}$ ages, younger ages ascribed to partial annealing of fission tracks by reheating on Earth's surface (Fleischer and Price, 1964), 3) $\mathrm{C}^{14}$ age of charcoal believed assoc. with australites, as well as geologic evidence, indicated age between last glacial and 6000 to 7000 B.P. (Gill, 1965). Although "ages" were inconsistent, field work on geology of australite occurrences favored the "younger" radiocarbon age. Australites are being eroded out of compacted eolian sand underlying recent seif dunes in Lake Torrens and Lake Eyre regions. Calcareous samples of horizons in which or above which australites occur coll. in 1965 by Lovering and 1967 by Mason subm. by Geophysics.

\section{ANU-28/2.}

$$
\begin{aligned}
\delta C^{14} & =-669.3 \pm 4.9 \\
\Delta & =-682.5 \pm 4.7
\end{aligned}
$$

$$
\delta C^{13}=-5.2 \pm 0.2 \%
$$

Calcareous sand at base of unconsolidated red sand dune, Pine Dams "Myrtle Springs", $24 \mathrm{mi}$ W of Leigh Creek (32 $26^{\prime} \mathrm{S}$ Lat, $138^{\circ} 01^{\prime}$ E Long). Australites found assoc. with this calcareous horizon. Benzene, $1340 \mathrm{~min}$. determination. Comment (H.A.P.): age confirms earlier determination of ANU-28 (Radiocarbon, 1967, v. 9, p. 19). Comment (J.F.L.): perfect preservation of delicate flanges of australites in area indicates that little transport occurred prior to assoc. with dated horizon. Comment G.E.W.): possibly related to ANU-280, 281 and 100 which are older than ANU-28.

ANU-45.

$$
\Delta=-51.9 \pm 13.4
$$

$430 \pm 110$

$$
\delta C^{13}=-21.6 \pm 0.2 \%
$$

Charcoal within hard "old soil" layer, $1.5 \mathrm{~m}$ below dune crest near Lake Peachawarrina $\left(29^{\circ} 01^{\prime} \mathrm{S}\right.$ Lat, $138^{\circ} 18^{\prime} \mathrm{E}$ Long). Carbonate nodules, ANU-82 derived from same horizon. Benzene, $320 \mathrm{~min}$. count. Comment (H.A.P.): age indicative of intrusive young charcoal not related to time of formation of "old soil." 
ANU-82.

$$
\delta C^{14}=-528.2 \pm 5.5
$$

$$
\Delta=-548.0 \pm 5.3
$$

$$
\delta C^{13}=
$$

$\mathbf{6 3 8 0} \pm \mathbf{9 5}$ count.

Carbonate nodules, Peachawarrina site, ANU-45. Benzene, 1380 min.

ANU-100.

$$
\begin{array}{rlr}
\delta C^{14} & =-835.0 \pm 5.0 & \mathbf{1 4 , 8 4 0} \pm \mathbf{2 5 0} \\
\Delta & =-842.3 \pm 4.8 & \delta C^{13}=-3.9 \pm 0.2 \%
\end{array}
$$

Calcareous nodules from surface of bench underlying sand at Pine Dam "Myrtle Springs". Australites found loose among nodules. Benzene, 1320 min. count. Comment (G.E.W.): date for calcareous soil development within sand dunes. See ANU-280 for other dates for same horizon.

$$
\text { ANU-127. } \begin{array}{rlr}
\delta C^{14} & =-916.6 \pm 3.7 & \mathbf{2 0 , 3 1 0} \pm \mathbf{3 6 0} \\
\Delta & =-920.2 \pm 3.6 & \delta C^{13}=-3.4 \pm 0.2 \%
\end{array}
$$

Unusually large calcareous nodules, $2 \mathrm{~m}$ below bench of ANU-100, Pine Dam, believed by G. E. W. to correlate with soil developed further $\mathrm{S}$ on the Lake Torrens plain represented by ANU-225. Benzene, 1340 min. count.

\section{Finke river series}

$\mathrm{S}$ bank of Finke R., $2 \mathrm{mi} \mathrm{N}$ of Idracowra Homestead (24 $59^{\prime} \mathrm{S}$ Lat, $133^{\circ} 44^{\prime}$ E Long). Vertical cliff ca. $30 \mathrm{~m}$ above river level, exposing 3 carbonate horizons. Australites not found at this site, but coll. in nearby surface deposits.

$$
\text { ANU-128. } \quad \begin{array}{rlr}
\delta C^{14} & =-854.7 \pm 10.5 & \mathbf{1 5 , 9 5 0} \pm \mathbf{4 2 0} \\
\Delta & =-864.1 \pm 10.0 & \delta C^{13}=-3.6 \pm 0.2 \% \circ
\end{array}
$$

Carbonate nodules in 1st horizon ca. $5 \mathrm{~m}$ below top of Finke R. cliff. Benzene, $2760 \mathrm{~min}$. count.

$$
\text { ANU-129. } \begin{array}{rlr}
\delta C^{14} & =-950.7 \pm 3.2 & \mathbf{2 4 , 5 6 0} \pm \mathbf{5 2 0} \\
\Delta & =-953.0 \pm 3.0 & \delta C^{13}=-2.9 \pm 0.2 \%
\end{array}
$$

Carbonate nodules in 2nd horizon ca. $13 \mathrm{~m}$ below top of Finke R. cliff. Benzene, 1360 min. count.

$$
\text { ANU-130. } \quad \begin{array}{rlrl}
\delta C^{14} & =-985.9 \pm 3.5 & \mathbf{3 4 , 3 2 0} \pm \mathbf{1 2 5 0} \\
\Delta & =-986.0 \pm 2.3 & \delta C^{13}=-3.5 \pm 0.2 \% o
\end{array}
$$

Large carbonate nodules in 3rd horizon ca. $23 \mathrm{~m}$ below top of Finke R. cliff. Benzene, 2140 min. count.

$$
\text { ANU-131. } \quad \begin{array}{rlr}
\delta C^{14} & =-960.5 \pm 4.0 & \mathbf{2 6 , 3 1 0} \pm \mathbf{8 2 5} \\
\Delta & =-962.2 \pm 3.8 & \delta C^{13}=-3.4 \pm 0.2 \%
\end{array}
$$

Carbonate nodules from same horizon as ANU-130, coll. laterally. Benzene, 1380 min. count.

General Comment (H.A.P.): 1st series of samples coll. at lab's request to check possibility of $\mathrm{C}^{14}$ dating of exposed secondary soil calcretions. Results, consistent with stratigraphic position, confirmed belief that under arid conditions initial $\mathrm{C}^{14} / \mathrm{C}^{12}$ ratio of formation could be preserved, and encouraged Bowler, Williams, Mason, and Lovering projects. 
ANU-132.

$$
\delta C^{14}=-780.3 \pm 6.0
$$

$12,540 \pm 150$

Calcareous nodules from surface of eolian erosion of overlying dund exposed by recent Numerous Numerous australites coll. on this surface; some reported in situ. See ANU-280 for other dates from this soil horizon. Benzene, 2660 min. count.

ANU-193.

$$
\begin{aligned}
\delta C^{14} & =-943.2 \pm 3.6 \\
\Delta & =-945.5 \pm 3.5
\end{aligned}
$$

$23,050 \pm 520$

Calcareous nodules on exposed heedy Sta. $\left(25^{\circ} 43^{\prime} \mathrm{S}\right.$ Lat, $121^{\circ} 56^{\prime} \mathrm{E}$ Lan with assoc. austraiites, EaraGeologic situation similar to that of Pine Dam, ANU-127, $1000 \mathrm{mi}$ to SE. Benzene. 1020 min. count.

General Comments (J.F.L., B.M., and G.E.W.): well-preserved australites are common in lag flooring corridors between seif dunes in Motpena area of Lake Torrens and Pine Dam and Nilpena sites. Study of Quaternary stratigraphy indicates that late Pleistocene relict sand dunes are most likely source, supporting assumption based on uniformity of physical and chemical composition that australites fell as single shower. Radiocarbon ages of calcareous nodules from soil horizon in which australites were found, ANU-28, 100, 280, 281 scatter round 13,000 \pm 3000 B.P. Varying of results could be indicative of uncertain, fluctuating amount of "dead" carbonate contamination of nodules, or that australites fell on eroded surface of eolian sediments and are assoc. with nodules of different ages at different places.

\section{Quaternary lakes}

Late Quaternary stratigraphy, chronology, and succession of lakes and assoc. features mainly in semiarid zone of SE Australia form part of independent study by J. M. Bowler, who coll. samples in 1968. Subm. by Dept. of Biogeog. and Geomorph.

\section{Willandra lakes series}

In $\mathrm{W}$ New South Wales, system of large dry lakes of area ca. 400 sq. mi, were maintained for long periods in late Quaternary by Willandra Creek (33 $00^{\prime} \mathrm{S}$ Lat, $144^{\circ} 23^{\prime} \mathrm{E}$ Long), effluent of the Lachlan R. With climatic change near end of Pleistocene, system became inactive due to reduction in stream flow and increased evaporation. Samples obtained to establish pattern of water-level oscillations, formation of lake-shore transverse dunes (lunettes), and linear or continental dunes with which lakes are assoc.

Three stratigraphic units have been recognized within eolian sediments and soils, informally named from youngest to oldest: Zanci, Mungo, and Golgol soil-sedimentary units. In these, soil formation alternated with active eolian deposition and lunette growth. Latter can be related to fluctuating water levels within active lakes, but soils formed during 
dry periods. Dates are listed from oldest to youngest, reflecting sequential development.

ANU-306.

$$
\begin{array}{rrr}
\delta C^{14}=-991.3 \pm 2.6 & \mathbf{3 8 , 5 0 0} \\
& & \mathbf{- 2 1 5 0} \\
\Delta & =-991.7 \pm 2.5 & \text { Est. } \delta C^{13}=-2.0 \pm 2.0 \%
\end{array}
$$

Unionid shells from gypseous lacustrine sandy clay exposed in gullied terrace on Outer Arumpo Lake floor ( $142^{\circ} 51^{\prime} \mathrm{S}$ Lat, $33^{\circ} 46^{\prime} \mathrm{E}$ Long) $4 \mathrm{mi} \mathrm{E}$ of Arumpo Sta. homestead. $10 \%$ (outer shell surface) by weight leached away by acid. Benzene, 3000 min. count. Comment (J.M.B.): age indicative of early high water level in low salinity environment.

ANU-305.

$$
\begin{aligned}
\delta C^{14} & =-988.0 \pm 2.7 \\
\Delta & =-988.5 \pm 2.6
\end{aligned}
$$

$+\mathbf{2 0 5 0}$

Est. $\delta C^{13}=-5.0 \pm 2$.

Ripple marked, cross-laminated shallow-water dolomite, from soil profile on lake-shore terrace, $500 \mathrm{~m} \mathrm{SW}$ from Mungo Sta. homestead, Lake Mungo ( $142^{\circ} 54^{\prime} \mathrm{S}$ Lat, $33^{\circ} 48^{\prime} \mathrm{E}$ Long). Benzene, $1980 \mathrm{~min}$. count. Comment (J.M.B.): affected post-depositionally by younger carbon, indicated by recrystallization visible on thin section. Age considered minimal for deposits which relate to terminal or drying phase before 40,000 B.P. probably correlating with late phase of Golgol deposition in dune stratigraphy.

$$
\text { ANU-331. } \quad \begin{array}{rlr}
\delta C^{14} & =-982.3 \pm 2.7 & \mathbf{3 2 , 7 5 0} \pm \mathbf{1 2 5 0} \\
\Delta & =-983.1 \pm 2.6 & \text { Est. } \delta C^{13}=-2.0 \pm 2.0 \%
\end{array}
$$

Unionid shells from deflation surface within dune on $\mathrm{S}$ end of "Walls of China", E shore, Lake Mungo. 12\% (outer shell surface) by weight leached away by acid. Benzene, $2000 \mathrm{~min}$. count. Comment (J.M.B.): shells represent early low salinity, high-water facies and appear assoc. with early human occupation. If further substantiated, it represents one of earliest dated occurrences of human occupation in Australia. Current work supports this interpretation. Shells underlie horizon of calcareous argillaceous sands blown from lake floor during drying, forming upper phase of Mungo deposition. Soil formed indicates lake was dry for considerable period after 32,000 в.P.

$$
\begin{aligned}
& \text { ANU-303. } \\
& \Delta=-976.8 \pm 2.7 \\
& 30,250 \pm 950 \\
& \text { Est. } \delta C^{13}=-24.0 \pm 2.0 \%
\end{aligned}
$$

Charcoal from remains of fire in red, cross-bedded sands of Mungo unit in Sec. E of Mungo Homestead. Benzene, 2040 min. count. Comment (J.M.B.): estimates age of Mungo deposition during terminal phase of lacustrine activity (drying of lake). This may suggest warm-climate oscillation ca. 30,000 B.P. 


\section{ANU-304.$$
\Delta=-965.0 \pm 11.2
$$

Charcoal from fire on disconformable contact at top of Unit $2 \mathrm{~m}$ in gullied profile through Outer Arumpo lunette $3 \mathrm{mi} \mathrm{W}$ from Joulni Homestead. Sample was sealed beneath younger bedded Zanci deposits. Charcoal horizon had developed on Mungo sediment on which marked soil formation had already taken place. Benzene dilution, 3620 min. count. Comment (J.M.B.): stability necessary for pedogenesis suggests dry-lake regime in period immediately preceding 27,000 B.P. This, with previous evidence, would place Mungo dry oscillation between ca. 27,000 and 30,000 B.P.

$$
\begin{aligned}
& \text { ANU.310. } \\
& \delta C^{14}=-943.0 \pm 3.9 \\
& \Delta=-945.3 \pm 3.7 \\
& \text { Est. } \delta C^{13}=-5.0 \pm 2.0 \%
\end{aligned}
$$

Tubular carbonate concretions in shallow-water sediments on $\mathrm{E}$ shore Lake Mungo, believed formed by precipitation around stems or roots of aquatic plants. Benzene, $1040 \mathrm{~min}$. count. Comment (J.M.B.): represents 1st high-water stand following Mungo low-water oscillation.

ANU-311.

$$
\begin{aligned}
\delta C^{14} & =-940.4 \pm 3.6 \\
\Delta & =-942.8 \pm 3.5
\end{aligned}
$$

Dolomitic sandstone exposed by deflation on the floor of Lake Chibnalwood. Dolomite cements shallow-water, well-sorted medium- to fine quartz sand representing shoreline or near-shore environment and low lake level. Benzene, 1020 min. count. Comment (J.M.B.): age appears to correlate with end of Mungo dry oscillation and onset of next highwater phase represented by carbonates in Lake Mungo, ANU-310.

$$
\text { ANU-329. } \quad \begin{aligned}
\delta C^{14} & =-880.2 \pm 4.1 \\
\Delta & =-885.0 \pm 4.0 \quad \text { Est. } \delta C^{13}=-5.0 \pm 2.0 \%
\end{aligned}
$$

Finely bedded calcareous sands from $1 \mathrm{~m}$ in gullied profile in Outer Arumpo lunette. Sample from highest or Zanci unit in lunette sequence overlying ANU-304. Benzene, 1220 min. count. Comment (J.M.B.): carbonate in form of pelletal aggregates and comminuted shell fragments from deflated lake floor believed to have been in near equilibrium with bicarbonate of lake waters and atmospheric $\mathrm{C}^{14}$ at time of drying. Age represents onset of final drying (Zanci oscillation).

ANU-321.

$$
\begin{array}{rr}
\Delta=-878.0 \pm 4.0 \quad & \mathbf{1 6 , 9 0 0} \pm \mathbf{2 7 0} \\
\text { Est. } \delta C^{1 s}=-24.0 \pm 2.0 \% \%
\end{array}
$$

Charcoal from fire remains sealed beneath Zanci sands immediately over disconformable contact with Golgol unit in Lake Garnpung lunette, Baymore Sta. Sample from basal level in Zanci unit represents early stage of Zanci deposition corresponding to onset of drying. Benzene, 1140 min. count. Comment (J.M.B.): agrees with ANU-329, relating same event to other parts of system. 
ANU-320.

$$
\begin{aligned}
\delta C^{14} & =-871.0 \pm 4.6 \\
\Delta & =-876.1 \pm 4.5
\end{aligned}
$$

$16,780 \pm 290$

Est. $\delta C^{13}=-5.0 \pm 2.0 \%$

Calcareous sandy clay from $1.5 \mathrm{~m}$ in profile on crest of Chibnalwood lunette. Carbonate occurs with pelletal clay aggregates with some shell fragments and, as in ANU-329, is believed to represent deposition from lake water during terminal, drying phase of Zanci oscillation. While ANU-329 dates beginning of that event in Arumpo-Chibnalwood lakes, ANU-320 represents conclusion of dune building or final drying of lake. Benzene, 1020 min. count. Comment (J.M.B.): small error due to incorporation of older carbon may be present but both ANU-329 and 320 provide results consistent with field evidence and other radiocarbon analyses.

"Walls of China", Lake Mungo series

$$
\begin{array}{llr}
\text { ANU-330. } & \mathbf{1 7 , 6 7 0} \pm \mathbf{5 5 0} \\
\text { Est. } \delta C^{13}=-24.0 \pm 2.0 \% & -889.2 \pm 7.2 \pm 0
\end{array}
$$

Charcoal fragments from base of Zanci calcareous sands $2.5 \mathrm{~m}$ above site of ANU-303 and $1.5 \mathrm{~m}$ above disconformable contact with red Mungo sands in Sec. E of Mungo Homestead. Benzene, 1280 min. count.

$$
\begin{aligned}
& \text { ANU-292. } \\
& \Delta=-875.0 \pm 9.1 \\
& 16,700 \pm 600 \\
& \text { Est. } \delta C^{13}=-24.0 \pm 2.0 \% \text { o }
\end{aligned}
$$

Charcoal from extensive horizon developed in middle of Zanci calcareous sands on $\mathrm{S}$ end of Lunette. Benzene, $1040 \mathrm{~min}$. count.
ANU-312.

$$
\Delta=-872.3 \pm 6.3
$$
$16,530 \pm 400$

$$
\text { Est. } \delta C^{13}=-24.0 \pm 2.0 \%
$$

Charcoal fragments from remains of fire sealed in Zanci calcareous sand ca. $6 \mathrm{~m}$ stratigraphically below upper limit on Sec. E from Mungo Homestead. Benzene, 1480 min. count.

$$
\text { ANU-319. } \quad \begin{array}{rlr}
\delta C^{14} & =-862.7 \pm 4.0 \\
\Delta & =-868.2 \pm 4.1 & \text { Est. } \delta C^{13}=-5.0 \pm 2.0 \%
\end{array}
$$

Bedded calcareous and argillaceous sand sealing ANU-312. ANU319 represents eolian sediment deposited contemporaneously. Selected to test Hypothesis that carbonate assoc. in eolian clay aggregates in lunette was precipitated in near $\mathrm{C}^{14}$ equilibrium conditions with lake water and atmosphere at time of deflation. Benzene, 1140 min. count. Comment (J.M.B.): remarkable agreement substantiating hypothesis and validating use of calcareous sediments for dating lunettes, where organic carbon is not available. Group ANU-292, 312, and 319 represents age of basal, middle, and upper zones of Zanci unit, in consistent sequence. Start of drying est. at ca. 17,500 B.P. correlates well with that determined by ANU-329 and 321; both relate to same event in other lakes.

\section{ANU-266.}

$$
\begin{aligned}
\delta C^{14} & =-846.2 \pm 4.0 \\
\Delta & =-853.3 \pm 3.9
\end{aligned}
$$

$15,400 \pm 210$

Unionid shells from trench excavated through lake shore sediments in inner $W$ margin of Lake Garnpung lunette, Golgol Sta. Benzene, 
1020 min. count. Comment (J.M.B.): age of youngest shells exposed in sediments, consistent with final drying. Lake Garnpung, on upstream end of system, probably received fresh-water inflow from waning discharge of Willandra Creek after Lakes Mungo and Chibnalwood had dried. Final drying in Lake Chibnalwood ca. 16,780 (ANU-320) occurs before that in Lake Garnpung represented by ANU-266.

ANU-293.

$$
\begin{aligned}
& \Delta=-848.1 \pm 15.5 \quad \mathbf{1 5 , 1 4 0} \pm \mathbf{8 5 0} \\
& \text { Est. } \delta C^{13}=-24.0 \pm 2.0 \%
\end{aligned}
$$

Charcoal from fire remains in sand overlying Zanci high-water level gravel in gully sec. through E edge of Lake Mungo, Joulni Sta. Benzene, 1040 min. count. Comment (J.M.B.): postdates final drying of lake, confirming interpretation based on dune stratigraphy as in ANU-312 and 292.

\section{Soil carbonate series}

Following experiences in soil-carbonate dating described earlier (this date list) 3 samples were selected to answer specific stratigraphic problems and test field hypotheses rather than further to test reliability of materials.

ANU-268.

$$
\begin{aligned}
\delta C^{14} & =-940.0 \pm 3.6 \\
\Delta & =-942.4 \pm 3.5
\end{aligned}
$$

Hard carbonate concretions in red calcareous Golgol $\delta .5 \pm 2.0 \%$ pung lunette at site fexpl soil in Garnpung lunette at site of excavation on Golgol Sta. Benzene, 1020 min. count.

ANU-270.

$$
\begin{aligned}
\delta C^{14} & =-972.2 \pm 2.7 \\
\Delta & =-973.3 \pm 2.6
\end{aligned}
$$

Est. $\delta C^{13}=-5.0 \pm 2.0 \%$ of Chir" carbonate concretions in red calcareous Golgol soil in "Walls of China", in Sec. E of Zanci Sta. Homestead. Benzene, 2020 min. count. Comment (J.M.B.): based on conclusions drawn from soil-carbonate project, ages of these samples are younger than sediments in which they occur. Age of Golgol deposition is older than 30,000 B.P.

ANU-269.

$$
\begin{aligned}
\delta C^{14} & =-715.0 \pm 4.7 \\
\Delta & =-726.4 \pm 4.6
\end{aligned}
$$

$10,400 \pm 140$

Soft carbonate concretions from a $2 \mathrm{nd}_{\mathrm{ca}}$ horizon apparently underlying that represented by ANU-270 analyzed to determine if 2 soilsedimentary units were present where only one had been suspected. Benzene, 1020 min. count. Comment (J.M.B.): young age indicates carbonate segregation later than that of main Golgol $B_{c a}$ represented by ANU-268 and 270. Re-examination of field evidence revealed pedogenetic carbonate from Zanci unit had been leached down into underlying Golgol on steep slope from which Zanci was later eroded. In this way, younger, soft carbonate appeared low in Sec. as if stratigraphically. underlying hard Golgol calcrete.

General Comment (J.M.B.): in view of variety of materials used and range of soil and sedimentary environments represented, agreement be- 
tween $\mathrm{C}^{14}$ results and field evidence is better than anticipated. Use of calcareous lunette sediments to date lunette building and lake drying is particularly significant. Excellent agreement between dates from contemporary organic carbon (ANU-312) and lake-derived inorganic carbon (ANU-319) needs further testing in other sites, but results suggest new approach to dating of formation of calcareous lunettes across South Australia and dating of climatic changes. Caution: before lunette sediments can be used thus, field and micropedologic analyses must establish sample has not been affected by secondary carbonate. If such evidence is present, younger $\mathrm{C}^{14}$ from soil-and atmospheric $\mathrm{CO}_{2}$ will be incorporated.

Each stratigraphic unit in dunes represents water-level oscillation with cyclic variation from high-water to low-water phase, controlled by variations of climate. Series established high-water phase from before 40,000 B.P., until some time after 33,000 B.P. Lowering of water levels and increased salinity followed, probably ca. 31,000 B.P., and at least some lakes remained dry for several thousand yrs corresponding to Mungo dry oscillation. Start of following wet phase begins ca. 25,000 B.P. This Zanci wet phase lasted until near 17,500 B.P. when, due to change in hydrologic budget, lake levels began to fluctuate and salinities increased, continuing until ca. 15,500 B.P., when discharge was insufficient to balance water lost by evaporation. Apart from occasional floods, system has remained inactive throughout the last $15,000 \mathrm{yr}$.

Sequence demonstrates effects of late Pleistocene cold phase equivaient to late-glacial climates of Northern Hemisphere, and provides 1st detailed chronology of late Quaternary environmental changes in the semiarid zone in South Australia.

\section{Lake Keilambete series}

To check climatic sequence, a deep-water lake was selected in $\mathrm{W}$ Victoria for comparison. Lake Keilambete near Terang $\left(38^{\circ} 10^{\prime} \mathrm{S}\right.$ Lat, $142^{\circ} 53^{\prime} \mathrm{E}$ Long) is volcanic, crater lake or maar, circular in plan, with rim diam. ca. $1.4 \mathrm{mi}$. Lake has small catchment area, limits of which are defined by crater rim. No streams discharge into it and groundwater increment is small compared to volume of water involved in direct precipitation, run-off from crater slopes, and evaporation. Fluctuations in water level apparent from both strandline features and from facies changes within core through lake sediment are therefore believed to directly reflect climatic variations. Salinity of present water is near $60,000 \mathrm{ppm}$ and is currently increasing annually due to falling water levels.

Maar lies in Miocene marine limestone which outcrops on margin of lake. Possibility of large limestone dilution error in lacustrine carbonates precipitated from lake waters in such an environment required evaluation before carbonates could be used for dating.

In shoreline stratigraphy, lacustrine limestone alternates with dark, calcareous, and organic rich lake muds. Initially, sequence of radiocarbon 
analyses of organic carbon in muds representing deep water facies was obtained through Inst. of Phys. and Chem. Research (RIKEN) Radiocarbon Lab., Tokyo. These provided basis for control of ages of shallowwater lacustrine limestones with which muds alternate. Three carbonate samples were analyzed to check reliability against those derived from organic carbon. Bowler has subsequently continued this project in cooperation with T. Hamada, RIKEN Lab, using contemporaneous organic and inorganic samples from cores from lake-floor sediment. In this latter series some additional 25 samples have been analyzed results of which will be reported separately.

$$
\text { ANU-197. } \quad \begin{aligned}
\delta C^{14} & =-116.0 \pm 7.4 \\
\Delta & =-165.5 \pm 7.0 \quad \delta C^{13}=+3.0 \pm 0.2 \%
\end{aligned}
$$

Lithified slabby lacustrine limestone overlying eroded tree remains recently emerged during falling water levels. Tree dated at $1890 \pm 115$ (N-390, Hamada, pers. commun.). Sample represents warm shallow water deposition during moderately low stand in lake level. Benzene, 1120 min. count.

\section{ANU-198.}

$$
\begin{aligned}
\delta C^{14} & =-362.0 \pm 6.4 \\
\Delta & =-398.1 \pm 6.2
\end{aligned}
$$

$$
\delta C^{13}=+3.3 \pm 0.2 \% 0
$$

Lithified, slabby lacustrine limestone stratigraphically underlying tree remains and rich organic lacustrine muds in which trees grew. Muds have been dated by organic carbon at $3820 \pm 120$ (N-388, Hamada, pers. commun.). Sample rests on lower organic rich lacustrine muds dated at $8690 \pm 165$ (N-389, Hamada, pers. commun.). Benzene, $1020 \mathrm{~min}$. count.

ANU-199.

$$
\begin{aligned}
\delta C^{14} & =-919.7 \pm 3.6 \\
\Delta & =-922.2 \pm 3.6
\end{aligned}
$$

Soft white lacustrine marl disconformably underlying lacustrine muds represented by N-389. Disconformity separating ANU-199 from younger samples assoc. with a buried soil; evidence of drying period between 20,500 and 9000 B.P. Benzene, $1020 \mathrm{~min}$. count.

General Comment (J.M.B. and H.A.P.): 3 samples dated are consistent with ages established by analyses of organic carbon, lending confidence to use of inorganic carbon in a saline, hard-water environment despite close contact with Tertiary limestone. In those samples, errors due to limestone dilution, if present, remain small. Results indicate lacustrine limestones were precipitated directly from lake water in which level of $\mathrm{C}^{14}$ activity was near equilibrium with atmospheric $\mathrm{C}^{14}$ levels at that time, a conclusion vindicated by more comprehensive analyses carried out by the RIKEN Lab.

General Comment (H.A.P.): our approach to problem of dating carconates (shell, coral, lake sediments, secondary soil calcretions, ground water concretions) was one of relating derived radiocarbon ages to ages based on organic materials from same horizons, supported by stratigraphic 
and geomorphic evidence, rather than physico-chemical argument (Ingerson and Pearson, 1964). Carbon-isotope data presented here and in Radiocarbon, 1969 , v. 11 , p. 245 , indicate that $\delta \mathrm{C}^{13}$ values are not always recognizably displaced from initial values while $\mathrm{C}^{14}$ migrates into recrystallizing carbonate (cf. Chappell, J. and Polach, H. A., 1969, Recrystallization processes in late Quaternary corals in light of isotope data: ms. on file). On completion of study, results will be further discussed independently by Bowler and Polach, and Williams and Polach.

\section{REFERENCES}

Date lists:

ANU I Polach, Stipp, Golson, and Lovering, 1967

ANU III

Polach, Chappell, and Lovering, 1969

Bowler, J. M., 1967, Quaternary chronology of Goulburn Valley sediments and their chronology in south-eastern Australia: Jour. Geol. Soc. Australia, v. 14, p. 287-292. 1969a, Alluvial terraces in the Maribyrnong Valley near Keilor, Victoria: Nat. Mus. Victoria Mem., in press.

1969b, Aeolian deposits, chronology and climatic history of the semi-arid zonc of south-eastern Australia: VIII Congress INQUA, Paris 1969, Resume des Communication, abs., p. 183.

Bowler, J. M. and Harford, L. B., 1966, Quaternary tectonics and the evolution of the Riverine Plain

Bowler, J. M., Mulvaney, D. J., Casey, D. A., and Darragh, T. A., 1967, Green Gully burial: Nature, v. 213, p. 152-154.

Churchward, H. M., 1961, Soil studies at Swan Hill, Victoria, 1. Soil layering: Jour. Soil Sci., v. 12, p. 73-86.

Fleischer, R. L. and Price, P. B., 1964, Fission track evidence for the simultaneous origin of tektites and other natural glasses: Geochim. et Cosmochim. Acta, v. 28, p. origin o

Geyh, M. A., 1969, Problems in radiocarbon dating of small samples by means of acetylene, ethane or benzene: Internatl. Jour. Appl. Radiation and Isotopes, v. 20, p. $463-466$.

Gill, E. D., 1965, Quaternary geology, radiocarbon datings, and the age of australites: Geol. Soc. America Spec. Paper, v. 84, p. 415-432.

Haynes, V., 1968, Radiocarbon: Analysis of inorganic carbon of fossil bone and enamel: Science, v. 161, p. 687-688.

Hills, E. S., 1939, The physiography of north-western Victoria: Roy. Soc. Victoria, Proc., v. 51, p. 300-323.

Ingerson, Earl and Pearson, F. J., Jr., 1964, Estimation of age and rate of motion of ground water by the carbon-14 method, in: Koyama, Tadashiro (ed.), Recent researches in the fields of hydrosphere, atmosphere and nuclear geochemistry, Mazuren, Tokyo, p. 263-283.

McDougall, Ian and Lovering, J. F., 1969, Apparent K-Ar dates on cores and excess Ar in flanges of australites: Geochim. et Cosmochim. Acta, v. 33, p. 1057-1070.

Polach, H. A., 1969, Optimisation of liquid scintillation radiocarbon age determinations and reporting of ages: Atomic Energy in Australia, v. 12, no. 3, p. 21-28.

Polach, H. A., Chappell, J., and Lovering, J. F., 1969, ANU radiocarbon date list III: Radiocarbon, v. 11, p. 245-262.

Polach, H. A. and Stipp, J. J., 1967, Improved synthesis technique for methane and benzene radiocarbon dating: Internatl. Jour. Appl. Radiation and Isotopes, v. 18,

p. 359-364. date list I: Radiocarbon, v. 9, p. 15-27.

Stace, H. C. T., Hubble, G. D., Brewer, R., et al., 1968, A handbook of Australian soils: Rellim Tech. Publ., S.A. for C.S.I.R.O. and Int. Soc. Soil Sci., p. 263-283.

Zähringer, J., 1963, K-Ar measurements of tektites, in: Radioactive dating, I.A.E.A. Symposium Proc., Athens, 1962, p. 289-305. 